\title{
The Role of Islamic Crowd Investing for Sustainable Agriculture in Indonesia
}

\author{
Ike Purnamasari ${ }^{*}$, Salina Kassim ${ }^{2}$ \\ 1, 2International Islamic University of Malaysia \\ ${ }^{1}$ Universitas Mulawarman, Indonesia \\ E-mail: 1ike.purnamasari@feb.unmul.ac.id, ${ }^{2} \mathrm{ksalina@iium.edu.my}$
}

*) Corresponding author

JEL Classification:

$\mathrm{O} 13$

Q14

Received: March 15, 2021

Revised: June 15, 2021

Accepted: July 15, 2021

\begin{abstract}
This research was conducted to discover the relationship between Islamic crowd investing and agriculture by exploring and analyzing the Islamic crowd-investing platform, and to describe the importance and benefits of sustainable agriculture in Indonesia. Funding platforms for agriculture are still relatively small in Indonesia. However, the potential for this sector is still very high due to the large number of demands and a large market. A systematic literature review with a qualitative approach research method was used in this study, specifically to review the literature retrieved from computerized databases, manual search, and authoritative texts related to Islamic crowd-investing and sustainable agriculture. This study showed a strong relationship explaining that financial technology, such as Islamic crowd-investing, has an important role not only in terms of funding, but also in achieving sustainable agriculture, which will have an impact on the environment that may potentiate the agricultural sector itself.
\end{abstract}

\section{Keywords:}

financial technology, Islamic crowd-investing, agriculture, sustainability.

\section{How to Cite:}

Purnamasari, I., \& Kassim, S. (2021). The Role of Islamic Crowd-Investing for Sustainable Agriculture in Indonesia. Signifikan: Jurnal Ilmu Ekonomi, 10(2), 343-358. https://doi.org/10.15408/sjie.v10i2.20060. 


\section{Introduction}

The rapid development of technology has an impact on the growth of business and financial services that use website-based technology as a platform. One of the new methods of financial innovation is the crowdfunding method (Belleflamme et al., 2015). This industry was initially used only as a medium for fundraising projects and social or humanitarian activities in the form of donations (Tan, Lu, \& Tan, 2016). However, with the development of this method and various forms of projects from organizers, this service is also used for financing, investing, or lending. Hence, this service is not only used for social-based endeavors, but also for profit-oriented businesses (Hornuf \& Schwienbacher, 2015). Agriculture is one such sector that makes crowdfunding to be primarily based on investment, i.e., crowd-investing (Mason-D'Croz et al., 2019). The agricultural sector should not be underestimated because it is one of the backbones of livelihood amongst the Indonesian population (Allo et al., 2017).

Investment-based crowdfunding, called crowd-investing, is a unique innovation that is usually carried out by new entrepreneurs who seek a collective venture capital from the crowd, i.e., the public (Tomczak \& Brem, 2013). This type of early business can be further developed into a larger business, often known as a start-up business (Rossi, 2014). The existence of various problems in the agricultural sector, such as the shift of land functions or the non-optimal changes of agricultural land management, has also received attention from various parties who are concerned with the agricultural problems in Indonesia (Alisjahbana \& Busch, 2017).

Furthermore, another factor of problems for farmers and the agriculture sector is the difficulty of obtaining access to capital or financing, resulting in lost opportunities of cultivating and managing agriculture, both from the upstream and downstream ends of this sector (Syuaib, 2016). Many improvements and arrangements are needed in this sector, one of which is the optimization of investment efforts through financial technology and financing digitization (Utama, 2013). Islamic agricultural crowd-investing is a type of fundraiser for a particular agricultural project by numerous individual contributions. Since agricultural projects require huge capital investments, crowd-investing helps farmers in acquiring capital by giving the opportunity to small-scale investors.

From the prevailing definition, crowd-investing is actually a part of crowdfunding, which is a new instrument in financing start-up businesses (Johnson et al., 2018). However, in Indonesia's context, financial technology companies with this business model are still related to peer-to-peer lending activities or borrowing from several people or individuals, which can also involve organizations and institutions (Iman, 2020). By utilizing the spirit of mutual cooperation or togetherness (gotong-royong), the operational system of this business often involves communities or groups of people who want to lend their funds, or participate in investments (Teja, 2017).

Equally, the use of financial technology is also incorporated in the agriculture sector, which has great potential for business (Hinson et al., 2019). Farmers who have limited funds and/or business capital, and have difficulty accessing credit from financial institutions 
will have the opportunity to take advantage of the digital financial service technology using the crowd-investing concept as an alternative resource to access a capital that may maximize their farming activities (Bi et al., 2017). In fact, capital is the main obstacle for most farmers, apart from other constraints, such as technology, market information, downstream crops, and climate change, especially for small-scale farmers (Amaruzaman et al., 2017).

Meanwhile, capital is an important internal factor in farming operations. In Indonesia, there are small-scale farmers who obtain capital only to set aside the expenditure to pay off farm operation costs from the previous period or season (Bashir \& Yuliana, 2019). With conditions and risks of uncertainty, farmers are at a disadvantage, further burdened by the daily needs of their families. This situation causes farmers to become entangled with adverse loan systems (Dufhues et al., 2011). It is not uncommon for farmers to borrow farming capital from various places. This path usually involves borrowing from financial institutions, both formal ones such as banks, savings, and loan cooperatives, farmer groups, and KUD; as well as non-formal ones such as loan sharks (Asikin et al., 2020).

Farmers often find it difficult to access capital from formal financial institutions (Meutia et al., 2017). In addition, farmers hold negative perceptions toward loans from formal financial institutions as being difficult and expensive (Mariyono, 2019). Farmers still lack detailed information on formal financial institutions and believe that the interest-based repayment system will ensnare them (Findiastuti et al., 2018). Therefore, this is the background for the emergence of the crowdfunding or crowd-investing concept, which can be used as an alternative media to access capital for agricultural activities.

With the intention of bringing together investors and consumers, this operation also functions as a financial intermediary for the farm financing system (Firdaus \& Aryanti, 2019). In line with this, the growth of various crowdfunding platforms in Indonesia facilitates agricultural projects or activities in obtaining capital assistance through digital media (Nassiry, 2018). To reach the masses, campaigns must be carried out in an effective manner (Kim et al., 2017), which involves three elements: the fund seekers or the founders; the crowd-investors; and the platform operators (Belleflamme et al., 2015). Although it is often easier and faster for raising funds (Kshetri, 2015), crowd-investors have little knowledge of the venture to be invested in. They completely rely on the information provided by the entrepreneur (Smith et al., 2017).

One of the great potentials of this platform is its ability to adhere to Islamic sharia values as part of business operations (Mujahidin, 2019). Islamic agricultural crowdinvesting is a type of fundraiser for a particular agricultural project by numerous individual contributions (Sakinah et al., 2018). Through the sharia crowd-investing approach, risk and liability issues can be managed by the farmers, while the platform becomes the financial intermediary (Saiti et al., 2018). This helps to attain production efficiencies within a form. Crowd-investing in the agriculture sector also imparts the knowledge on agriculture to investors, consumers, and allied enterprises (Ordanini et al., 2011). 
Table 1 shows some of the crowdfunding/investing financial technology companies that focus on the agriculture sector as of 14 October 2020, obtained from the Financial Service Authority. Based on the Table 1, the data released by the Financial Service Authority show only few companies with a core business in the agricultural sector. In fact, most of their main businesses usually finance SMEs. However, because there is a market opportunity for agriculture, they still cater to this sector (Mcintosh \& Mansini, 2018). This confirms that the agricultural potential is actually very high, since many people still care about agriculture in Indonesia (Suasih \& Yasa, 2017). Apart from that, many residents in rural areas are involved in agriculture as one of their livelihoods, demanding this sector to be fully supported by various parties (Wright et al., 2016).

Table 1. Crowdfunding/Crowd-Investing Agriculture in Indonesia.

\begin{tabular}{cccc}
\hline Name of Company & Core Business & System & Status from OJK \\
\hline Igrow Asia & Agriculture & Conventional/Profit Sharing & Licensed \& Listed \\
Crowde & Agriculture & Conventional & Licensed \& Listed \\
Tanifund & $\begin{array}{c}\text { Agriculture (Upstream } \\
\text { \&Downstream) }\end{array}$ & Conventional/Profit Sharing & Licensed \& Listed \\
Lahan Sikam & Agriculture & Conventional & Licensed \& Listed \\
Crowdo & Agriculture, MSMEs & Conventional & Licensed \& Listed \\
Goolive & Agriculture & Sharia-Based & In Process \\
Tanijoy & Agriculture & Sharia-Based & In Process \\
MyAgroLand & Agriculture, Land, Field & Sharia-Based & Not Registering \\
Vestifarm & Agriculture $\&$ & Conventional & In Process \\
Santara & Aquaculture & Conventional & Newcomer, In Process \\
\hline
\end{tabular}

Source: (OJK Indonesia, 2020); Modified by Author

Interestingly, from Table 1, only two of the few companies that obtained permits and have registered with the regulatory agency actually adopt sharia principles in their business operations. The remaining companies only state this on their platforms, but from a legal standpoint in accordance to the criteria set by the institutional authority, they operate with a conventional system instead (Ansori, 2019). Ironically, this practice is contrary to the Muslim majority of the Indonesian society (Djawahir, 2018).

Since the Financial Services Authority and the National Sharia Council have issued 'fatwas' (rulings) for digital financial transactions, especially those related to digital transactions based on sharia principles. Several businesses, such as crowdfunding platforms, have also tried to apply this to their business systems. This present paper has emphasized that crowd-investing is a business model that can enhance and sustain agriculture in Indonesia (Strzębicki, 2015; Teja, 2017) by offering an alternative financing form of 
loans or investment, in addition to the existing services offered by financial institutions (Lee et al., 2018).

In the Indonesian context, several financial technology platforms do have great motivation to develop the agriculture sector and help farmers in terms of capital. This provides an opportunity for the agriculture sector to continue to be developed (Ningrat \& Nurzaman, 2019). However, the great potential possessed by this sector is not directly proportional to its implementation. Based on the data released by the Financial Services Authority in the second semester of 2020, only several financial technology companies were concerned with agriculture, and have registered or received operational licenses from the OJK as regulators. Other companies registered with regulatory agencies are more focused on financing or microfinancing other investments outside agriculture, such as property - micro, small, and medium enterprises; and other retail businesses (Mittelman \& Rojas-Méndez, 2013).

There are many studies that focuses more on developing in depth "fintech" crowdfunding or crowd-investing, such as the characteristics of successful crowd-funding (Yuan et al., 2016), and the factors that influence it (Zhao et al., 2017). On the other hand, few studies discuss this fintech platform with sustainable agriculture. Other researches focus more on microfinance for the MSME sector (Pronti \& Elena, 2019; Sa'ad et al., 2019), or more emphasis on the discussion of the consumptive loan process for the household sector of the economy (Gimpel et al., 2018). Furthermore, there are several studies that discuss the agriculture sector, but explore more on the business model and those associated with the marketplace in this industry (Anshari et al., 2019; Ningrat \& Nurzaman, 2019; Strzębicki, 2015).

False assumption is the notion that there are not many financial technology companies operating with the concept of crowdfunding or crowd-investing applications on agriculture (Mcintosh \& Mansini, 2018). Similar designs and study models related to this matter are relatively few. For example, one study by Mariyono (2019) focused on the access to financing in terms of using microcredit capital in agricultural management, especially in Indonesia. Another study by Muhyiddin (2018) discussed more on the distribution flow or the transformation of agriculture to the manufacturing industry as part of the sector's development. Although, the attention paid by world institutions shows the support for global agriculture. According to one report by World Bank (2013), there is a need for microfinance institutions to optimize financing for agribusiness, whereas another report by World Bank (2016) stated that digitalization is also needed in maximizing the development of the agricultural sector. Hence, in this paper, we have explored the connection of Islamic crowd-investing and sustainable agriculture in Indonesia, which is still rarely discussed by other researchers. Based on several gaps from the studies that have been described previously, this research aims to discover the relationship between Islamic crowd-investing and the agriculture sector by exploring and analysing the Islamic crowd-investing platform thorough literature. Besides that, the aims of this research also to describe the importance and benefit of sustainable agriculture in Indonesia. 


\section{Method}

The methods used are qualitative systematic review with an integrative analysis through documents or literature. The systematic review offers several advantages compared to the conventional literature review. The review can be strengthened via a transparent article-retrieving process, a more prominent or wider area of research, and more significant objectives, which can control research bias. Apart from that, this also motivates a researcher to produce quality evidence with more significant results (Johnson \& Hennessy, 2019). Key texts (henceforth, referred to as "guidance") are identified based on accessibility and prominence within the United Kingdom's systematic reviewing practice (Cooper et al., 2018). The value of systematic review depends on what was done, what was found, and what was clarified from the reporting (Sierra-Correa \& Cantera Kintz, 2015; Moher et al., 2015 Okoli, 2015).

The review methods of the present study were conducted using two databases, namely Scopus and Open Knowledge Maps, considering that both databases are reputable. In relation to studies on crowd-investing in agriculture, more than 134 articles in Emerald, 20 results in Scopus, and 56 journals of open access type and non-open access type in Open Knowledge Maps were covered. The appropriateness of this methodology for crowd-investing and agriculture studies review is reflected in four ways (Sierra-Correa \& Cantera Kintz, 2015): (i) clearly defining research questions; (ii) explicitly identifying inclusion and exclusion criteria; (iii) assessing a large amount of relevant and available scientific literature as much as possible in a definite time; and (iv) increasing the rigor by using statistics (Morton et al., 2016; Johnson \& Hennessy, 2019). A systematic review aims to minimize bias by using explicit methods, and to identify the gaps as well as new directions for future research.

\section{The Systematic review process for selecting articles Identifications}

In this process, a number of present relevant articles were searched, collected, and selected from the databases. With the identification of keywords, this was followed by a search for related and similar terms regarding the topic of research. Therefore, a search string in terms of keywords in Scopus resulted in a total of 156 journal publications. As previously stated, the Open Knowledge Maps scientific database yielded 56 journals and additional records identified through other sources - Science Direct, Taylor Francis, Springer, MDPI database result 13 journals.

\section{Screening}

In this process, ten articles were excluded in the first stage, while 225 articles were screened based on several inclusion and exclusion criteria determined by the researchers in the second stage. The first criterion is the literature type, in which the researchers decided to only focus on journals (research articles) because they act as the primary sources that offer empirical data. Hence, this implies that publications in the form of 
systematic review, review, meta-analysis, meta-synthesis, book series, books, chapters in books, and conference proceedings were excluded from the current research. In addition, it should be noted that the review only focused on articles that had been published in English.

\section{Eligibility}

In the third stage, 115 articles were prepared for screening eligibility. On a more important note, the titles, abstracts, and the main content of all articles in this stage were examined thoroughly to ensure that they fulfil the inclusion criteria of the present study to achieve the research objectives. Consequently, a total of 96 articles were excluded because they were not based on empirical data, and were discovered to be hard sciences articles or those that do not focus on agricultural practices in Asian countries and territories. Finally, a total of 19 remaining articles were ready to be analysed.

\section{Model Development (Data Abstraction)}

Full articles were assessed for eligibility. Efforts were concentrated on specific studies that responded to the formulated research questions. The table below shows the inclusion and exclusion criteria of the databases that were searched for extraction and analysis it.

Table 2. The inclusion and exclusion criteria.

\begin{tabular}{lll}
\hline \multicolumn{1}{c}{ Criterion } & \multicolumn{1}{c}{ Eligibility } & \multicolumn{1}{c}{ Exclusion } \\
\hline Literature type Journal & $\begin{array}{l}\text { Journals (research articles) indexed } \\
\text { by Scopus }\end{array}$ & $\begin{array}{l}\text { Journals (review), book series, } \\
\text { books, chapters in books, } \\
\text { conference proceedings }\end{array}$ \\
Language & English & $\begin{array}{l}\text { Non-English } \\
\text { Time line }\end{array}$ \\
Subject area & Between 2018 and 2020 & $<2019$ \\
& $\begin{array}{l}\text { Social Science, Crowdfunding, } \\
\text { Crowd-Investing, Islamic } \\
\text { Crowdfunding in Agriculture }\end{array}$ & $\begin{array}{l}\text { Other than Social Science, or } \\
\text { Crowdfunding, or Crowd-Investing, } \\
\text { or Islamic Crowdfunding in } \\
\text { Agriculture }\end{array}$ \\
\hline
\end{tabular}

This study performed a comprehensive review technique that analysed and synthesized diverse research designs in the qualitative approach (see Table 2). The process of developing the appropriate themes and subthemes was carried out based on thematic analysis (Shaffril et al., 2019)The first phase of the theme development process was the compilation of data. In this phase, the authors carefully analysed a group of 19 selected articles to extract statements or data that answer the research questions. Subsequently, in the second phase, the authors created meaningful groups via a coding method according to the nature of the data. In other words, the second phase converts raw data into useable data via the identification of themes, concepts, or ideas for more connected data (Charrois, 2015). 


\section{Results and Discussion}

Based on Figure 1, the systematic review process is explained thoroughly, including analysing and synthesizing the selected final studies for the qualitative synthesis. This process starts from identifying existing database in the online literature (Scopus, Open Knowledge Maps, Science Direct, Taylor and Francis, and MDPI Journal), and is based on some of the criteria mentioned earlier. Then, duplicate records will be removed from the database. Moreover, after the duplicates' removal, several articles were screened to define the exclusion and inclusion criteria of publication. Thus, the final result to analyse was 19 articles, which were selected in the qualitative synthesizes.

As a final point, the process has resulted in the development of three main themes, namely performance of crowd-investing in agriculture, sharia compliance, and sustainable agriculture. Meanwhile, for the subthemes, codes were created which related to project category, funding target, lender motivation, sharia application, and food sustainability. Thereafter, the authors resumed the process in each of the created theme, whereby any theme, concept, or idea that had connections with one another within the developed theme would be channelled into subthemes. Table 3 below shows the result of the data extraction from Figure 1.

Figure 1. The Systematic Review Process

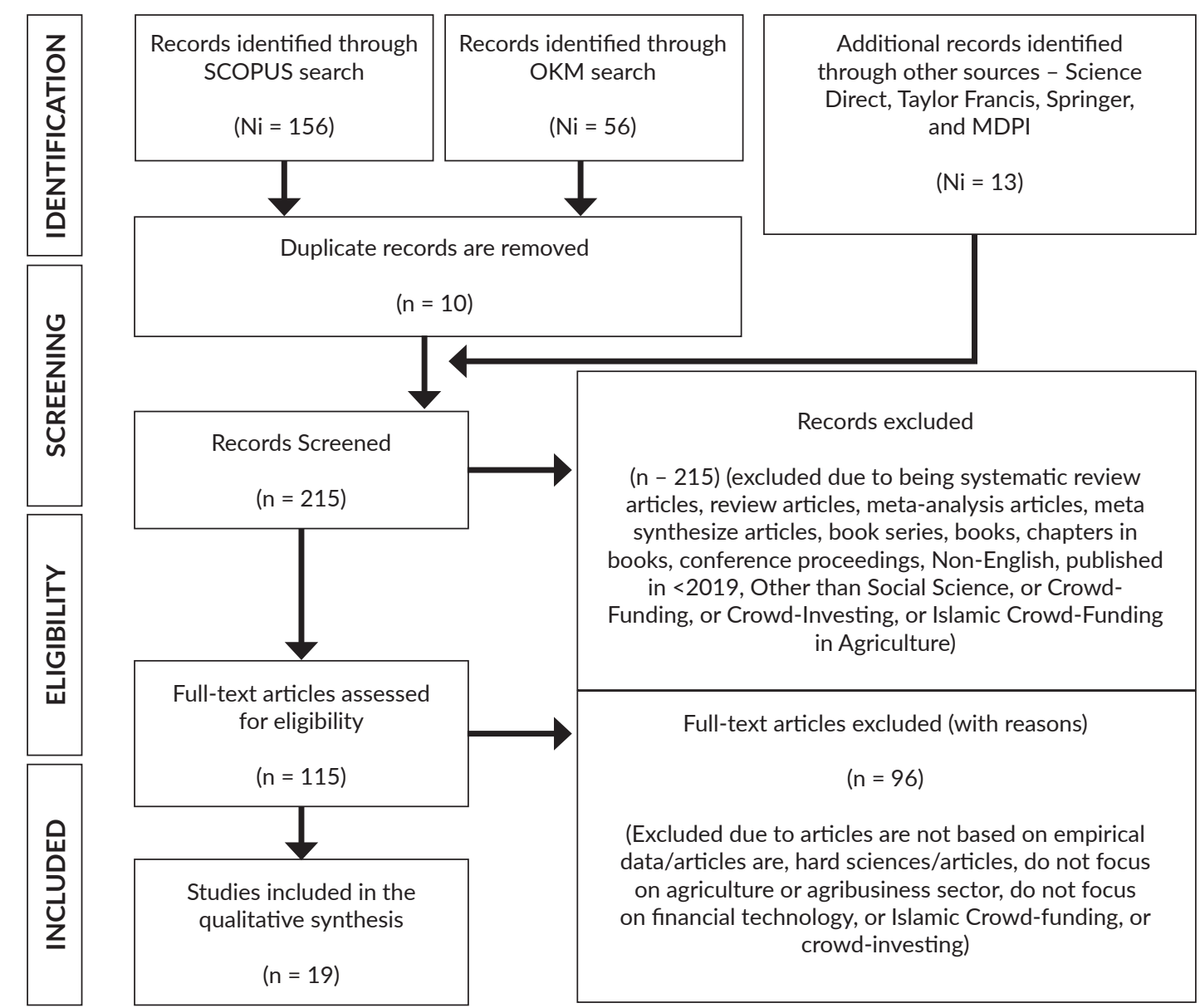

Source: adapted from Moher et al. (2015). 
Table 3. The Role of Islamic Crowd-Investing toward Sustainable Agriculture

\begin{tabular}{|c|c|c|c|c|c|c|}
\hline \multirow{2}{*}{ No } & \multirow{2}{*}{ Authors } & \multicolumn{3}{|c|}{ Performance Crowd Investing Agriculture } & \multirow{2}{*}{$\begin{array}{c}\begin{array}{c}\text { Sharia } \\
\text { Compliance }\end{array} \\
\begin{array}{c}\text { Sharia } \\
\text { Application }\end{array}\end{array}$} & \multirow{2}{*}{$\begin{array}{c}\begin{array}{c}\text { Sustainability } \\
\text { Agriculture }\end{array} \\
\text { Food } \\
\text { Sustainability }\end{array}$} \\
\hline & & $\begin{array}{l}\text { Project } \\
\text { Category }\end{array}$ & $\begin{array}{l}\text { Funding } \\
\text { Target }\end{array}$ & $\begin{array}{l}\text { Lender } \\
\text { Behaviour }\end{array}$ & & \\
\hline 1 & Chang (2018) & $v$ & v & v & - & - \\
\hline 2 & $\begin{array}{l}\text { Ningrat \& Nurzaman } \\
\text { (2019) }\end{array}$ & - & $\mathrm{v}^{*}$ & $\mathrm{v}^{*}$ & $\mathrm{v}^{*}$ & $\mathrm{v}^{* *}$ \\
\hline 3 & Fitriani (2018) & $\mathrm{v}^{*}$ & $\mathrm{v}^{*}$ & - & $\mathrm{v}^{*}$ & $\mathrm{v}^{* *}$ \\
\hline 4 & Hinson et al. (2019) & $v$ & - & - & - & $\mathrm{v}^{* *}$ \\
\hline 5 & $\begin{array}{l}\text { Firmansyah \& Anwar } \\
\text { (2019) }\end{array}$ & $v^{*}$ & - & $\mathrm{v}^{*}$ & $\mathrm{v}^{*}$ & $\mathrm{v}^{* *}$ \\
\hline 6 & Anshari et al. (2019) & $\mathrm{v}^{*}$ & - & $\mathrm{v}^{*}$ & $v^{*}$ & $\mathrm{v}^{* *}$ \\
\hline 7 & $\begin{array}{l}\text { Mclntosh \& Mansini } \\
(2018)\end{array}$ & $\mathrm{v}$ & - & $v$ & - & $\mathrm{v}^{* *}$ \\
\hline 8 & Yoo \& Choe (2014) & $v$ & - & $v$ & - & $\mathrm{v}^{* *}$ \\
\hline 9 & Nassiry (2018) & - & $v$ & - & - & $\mathrm{v}^{* *}$ \\
\hline 10 & Saiti et al. (2018) & $\mathrm{v}^{*}$ & $\mathrm{v}^{*}$ & $\mathrm{v}^{*}$ & $\mathrm{v}^{*}$ & $\mathrm{v}^{* *}$ \\
\hline 11 & Misso \& Cesaretti (2019) & $v$ & $v$ & $v$ & - & $\mathrm{v}^{* *}$ \\
\hline 12 & Muhyiddin (2018) & $v$ & $v$ & $v$ & - & $\mathrm{v}^{* *}$ \\
\hline 13 & $\begin{array}{l}\text { Sa'ad, Ahmad, \& Saleh } \\
\text { (2019) }\end{array}$ & $\mathrm{v}^{*}$ & $\mathrm{v}^{*}$ & $\mathrm{v}^{*}$ & $\mathrm{v}^{*}$ & $\mathrm{v}^{* *}$ \\
\hline 14 & Nielsen (2017) & $v$ & $v$ & $v$ & - & $\mathrm{v}^{* *}$ \\
\hline 15 & Motylska-kuzma (2018) & $v$ & $v$ & $v$ & - & $\mathrm{v}^{* *}$ \\
\hline 16 & $\begin{array}{l}\text { Filimonova \& Ozerova } \\
\text { (2019) }\end{array}$ & v & $v$ & $v$ & - & $\mathrm{v}^{* *}$ \\
\hline 17 & Asfarian (2020) & $v$ & $v$ & $v$ & - & $\mathrm{v}^{* *}$ \\
\hline 18 & Maehle (2020) & $v$ & $v$ & $v$ & - & $\mathrm{v}^{* *}$ \\
\hline 19 & Li, Du, \& Fu (2020) & v & $v$ & $v$ & - & $\mathrm{v}^{* *}$ \\
\hline
\end{tabular}

Note:

*Publication with topic sharia compliance and sustainability agriculture

**Publication without sharia compliance

The analysis produced a total of three themes and five subthemes related to the role of Islamic crowd investing in the agriculture sector and sustainable agriculture. As presented in Table 3, the three themes are performance of crowd-investing agriculture (three subthemes), sharia compliance (one subtheme), and sustainability agriculture (one subtheme). More specifically, it should be noted that several selected and eligible paper themes were found to have revealed crowdfunding or crowd-investing performance through their performance projects, while 6 (six) other papers highlighted the importance of sharia compliance to be applied, and the rest focused more on sustainable agriculture models and the systems inside them. Nonetheless, if all papers had been synthesized based on subthemes, each theme could have been connected to other codes. Despite this, not all papers were connected to other themes or subthemes. Yet, in the papers by Fitriani (2018), the findings emphasize that the role of financial technology (crowdfunding/investing/p2p 
lending), especially in this digital era, is to further strengthen farmers' capital, in order to optimize facilities and infrastructure for the realization of the sustainability of the agriculture sector in Indonesia.

Meanwhile, Anshari et al. (2019) provide a concept where digital marketplaces and fintech can bridge farmers, investors, and land owners, and can expand the supply chain as well as sustainability in the agriculture sector. This is in line with Ningrat $\&$ Nurzaman (2019), where it was conveyed that fintech and Islamic finance can realize a sustainable agriculture value chain. Moreover, Firmansyah \& Anwar (2019) mentioned that one of the Islamic crowd-investing companies in the agriculture sector is Goolive as mentioned earlier in Table 1. This confirms that the role of this company has promising prospects if it is optimized and managed with good organization. On a global scale, the role of fintech, whether crowdfunding/investing or p2p lending, has also been conveyed by Saiti et al. (2018) and Sa'ad et al. (2019); those who focus more on the concept of their own financing, namely by using 'salaam' and/or through the 'musharakah' smart contract mechanism, in order to maximize funding in the agriculture sector and this is very possible if implemented in the context of agriculture in Indonesia. Based on previous analyses, this study can represent the research objective (i) regarding the relationship between Islamic crowd investing and the agriculture sector in Indonesia.

Furthermore, to describe the importance and benefit of sustainable agriculture in Indonesia and at a global scale as in research objective (ii), a study by Hinson et al. (2019) revealed the important role of fintech crowd-investing toward the success of sustainable agriculture. Thus, making it part of the development in an effort to realize the SDG as a goal or vision. The study also explained that the role of the Internet is instrumental in the digitalization of the financial sector, so it needs to be improved in relation to other sectors such as agriculture. This was also further stated by McIntosh \& Mansini (2018) that the optimization of non-bank financial institutions does not make them distracting, since their presence is able to maximize the functions and empowerment related to the agricultural sector, both for farmers and their surrounding environment such as the community, the society, and the market or industry from upstream to downstream. Moreover, Misso \& Cesaretti (2017) explained that the internet and its development play an important role through crowdfunding in maximizing the sustainability of agri-food and agri-enterprise, and to develop a society with higher well-being. In Indonesia, Asfarian (2020) described the designing about mobile crowdfunding to reduce food insecurity and to implement the food security as an innovation through technology, internet, and fintech. Along with other researchers, agri-food through crowdfunding/crowd-investing can also have an impact on a sustainable food community as well as communication, and the factors influence the success of the campaign in order for it to run smoothly (Yoo \& Choe, 2014; Pronti \& Elena, 2019).

Henceforth, this study has presented the main result of the relationship between Islamic crowd investing and agriculture sector in Indonesia, and the benefit of sustainable agriculture, which can then be summarized below: 


\section{The Relationships:}

1. Optimizing farmers' capital because it is accessible.

2. Increasing the availability of infrastructure needed by farmers.

3. Islamic crowd-investing can encourage the creation of digital marketplace agriculture in order to realize sustainability.

4. To bridge farmers, investors, and landowners.

5. Through Islamic crowd-investing, it can create supply chain agriculture.

6. 'Salaam' and 'Musharakah' as a process that can maximize funding disbursement in agriculture.

\section{The Benefits:}

1. The minimization in food insecurity.

2. The creation of sustainable agriculture value chain.

3. The implementation of agri-food and agri-enterprise.

4. The realization of sustainable food community toward the well-being of society.

5. The achievement of one of the SDGs Goals.

\section{Conclusion}

PRISMA is a tool that is relatively comprehensive to use in observing phenomena related to a literature. By reviewing it more in-depth and in detail, it is hoped that research gaps can be detected, whether a study has been done or (maybe) has not been completed by previous researchers. From the systematic review, a guideline can be created, compiled, and collated to use by other researchers in continuing or complementing existing research. In this study, the findings contained in the abstraction data did not limit the existence of codes, themes, and other subthemes that had not been included (or revealed) in this study. However, the existing directions can be used as a basis for reviewing the same topic further and for adding new findings to the latest research. Therefore, the role of Islamic crowd investing has seen an emergence within the agricultural development in Indonesia. Nonetheless, the potential for this sector cannot stand alone, and needs the support from stakeholders and shareholders who are concerned with agriculture as well as its ecosystems.

This research only focuses on the agricultural sector in Indonesia that still needs to be optimized more broadly. Several literatures have found that the relationship between Islamic crowd-investing and sustainable agriculture, if managed properly and by creating new innovations, will certainly be able to achieve food security and reduce the potential for vulnerable food societies in the future.

Based on the results of this research and the conclusion above, this study recommends several policies. As a new financial innovation, crowd investing tries to develop and improve the implementation of sharia regulations. Since it must comply with the system, the government must accommodate supervising and monitoring this application. Building 
a digitalization of the ecosystem requires a lot of support from all parties; especially in the increasingly broad financial technology industry; strong infrastructure and optimizing practitioners in this industry are also expected to be maximized. Moreover, capacity building is intrinsic for the maintenance of the world of agriculture, both of locally and globally as well as vertically and horizontally, is urgently required. Hence, the link between industries, such as among crowd-investing fintech and the agriculture sector, can provide functions and benefits that can be experienced by farmers at large.

\section{References}

Alisjahbana, A. S., \& Busch, J. M. (2017). Forestry, Forest Fires, and Climate Change in Indonesia. Bulletin of Indonesian Economic Studies, 53(2), 111-136. https://doi. org/10.1080/ 00074918.2017.1365404

Allo, A. G., Sukartini, N. M., \& Widodo, T. (2017). Dynamic Changes in Comparative Advantage of Indonesian Agricultural Products. Munich Personal RePEc Archive, 80028.

Amaruzaman, S., Leimona, B., Noordwijk, M. Van, \& Lusiana, B. (2017). Discourses on The Performance Gap of Agriculture in a Green Economy: a Q-Methodology Study in Indonesia. International Journal of Biodiversity Science, Ecosystem Services \& Management, 13(1), 233-247. https://doi.org/10.1080/21513732.2017.1331264

Anshari, M., Almunawar, M. N., Masri, M., \& Hamdan, M. (2019). Digital Marketplace and FinTech to Support Agriculture Digital Marketplace and FinTech to Support Agriculture Sustainability Sustainability Assessing the Feasibility Using The Masairol Heat Demand-Outdoor Brunei Forecast Temperature Function District Heat. Energy Procedia, 156, 234-238. https://doi.org/10.1016/j.egypro.2018.11.134

Ansori, M. (2019). Perkembangan Dan Dampak Financial Technology (Fintech) Terhadap Industri Keuangan Syariah Di Jawa Tengah. Wahana Islamika: Jurnal Studi Keislaman, 5(1), 31-45.

Asfarian, V. W. A. (2020). E-Initiative for Food Security : Design of Mobile Crowdfunding Platform to Reduce Food Insecurity in Indonesia. Proceeding at Conference: 2020 8th International Conference on Information and Communication Technology (ICoICT).

Asikin, Z., Baker, D., Villano, R., \& Daryanto, A. (2020). Business Models and Innovation in The Indonesian Smallholder Beef Value Chain. Sustainability, 12(17), 1-13. https://doi.org/10.3390/su12177020

Bashir, A., \& Yuliana, S. (2019). Identifying Factors Influencing Rice Production and Consumption in Indonesia. Jurnal Ekonomi Pembangunan: Kajian Masalah Ekonomi dan Pembangunan, 19(2), 172-185. https://doi.org/10.23917/jep.v19i2.5939

Belleflamme, P., Omrani, N., \& Peitz, M. (2015). The Economics of Crowdfunding Platforms. Information Economics and Policy, 33, 11-28. https://doi.org/10.1016/j. infoecopol.2015.08.003

Bi, S., Liu, Z., \& Usman, K. (2017). The Influence of Online Information on Investing Decisions of Reward-based Crowdfunding. Journal of Business Research, 71, 10-18. https://doi.org/10.1016/j.jbusres.2016.10.001 
Chang, W. I. (2018). Exploring Crowdfunding Performance of Agricultural Ventures: Evidence from FlyingV in Taiwan. Lecture Notes of the Institute for Computer Sciences, Social-Informatics and Telecommunications Engineering, LNICST, 208, 165-173. https://doi.org/10.1007/978-3-319-66742-3_16.

Charrois, T. L. (2015). Systematic Reviews : What Do You Need to Know to Get Started ? The Canadian Journal of Hospital Pharmacy 68(2):144-8, 68(2), 144-148.

Cooper, C., Booth, A., Varley-campbell, J., Britten, N., \& Garside, R. (2018). Defining The Process to Literature Searching in Systematic Reviews: A Literature Review of Guidance and Supporting Studies. BMC Medical Research Methodology, 18(1), 1-14.

Djawahir, A. U. (2018). Teknologi-layanan Keuangan, Literasi-inklusi Keuangan, dan Value pada Fintech Syariah di Indonesia: Perspektif S-O-R (Stimulus-organism-response) Model. In 2nd Proceedings Annual Conference for Muslim Scholars, 439-448.

Dufhues, T., Buchenrieder, G., Euler, D. G., \& Munkung, N. (2011). Network Based Social Capital and Individual Loan Repayment Performance. Journal of Development Studies, 47(8), 1199-1215. https://doi.org/10.1080/00220388.2010.547936.

Findiastuti, W., Singgih, M. L., \& Anityasari, M. (2018). Indonesian Sustainable FoodAvailability Policy Assessment Using System Dynamics: A Solution for Complexities. Cogent Food \& Agriculture, 102(1), 1-21. https://doi.org/10.1080/23311932.2018.1 455795

Firdaus, D. W., \& Aryanti, R. K. (2019). The Influence of Financial Technology in Financial Transactions. IOP Conference Series: Materials Science and Engineering, 662(2), 022012. https://doi.org/10.1088/1757-899X/662/2/022012

Firmansyah, E. A., \& Anwar, M. (2019). Islamic Financial Technology (FINTECH): Its Challenges and Profile of the Islamic Fintech Firms The six Islamic Fintech Firms Participating in This Research are The Firms Headquartered in Indonesia. Advances in Social Science, Education and Humanities Research (ASSEHR), 216, 52-58.

Fitriani, H. (2018). Kontribusi Fintech dalam Meningkatkan Keuangan Inklusif pada Pertanian. El Barka: Journal of Islamics Economics and Business, 1(1), 1-26.

Gimpel, H., Rau, D., \& Röglinger, M. (2018). Understanding FinTech Start-ups - A Taxonomy of Consumer-Oriented Service Offerings. Electronic Markets, 28, 245264. https://doi.org/10.1007/s12525-017-0275-0

Hinson, R., Lensink, R., \& Mueller, A. (2019). ScienceDirect Transforming Agribusiness in Developing Countries: SDGs and The Role of FinTech. Current Opinion in Environmental Sustainability, 41, 1-9. https://doi.org/10.1016/j.cosust.2019.07.002

Hornuf, L., \& Schwienbacher, A. (2015). Funding Dynamics in Crowdinvesting. Research Papers in Economics. University of Trier.

Iman, N. (2020). The Rise and Rise of Financial Technology: The Good, The Bad, and The Verdict The Rise and Rise of Financial Technology: The Good, The Bad, and The Verdict. Cogent Business \& Management, 7(1), 1-17. https://doi.org/10.1080/2 3311975.2020 .1725309

Johnson, B. T., \& Hennessy, E. A. (2019). Social Science \& Medicine Systematic Reviews and Meta-Analyses in The Health Sciences: Best Practice Methods for Research 
Syntheses. Social Science \& Medicine, 233, 237-251. https://doi.org/10.1016/j. socscimed.2019.05.035

Johnson, M. A., Stevenson, R. M., \& Letwin, C. R. (2018). A Woman's Place is in the... Startup! Crowdfunder Judgments, Implicit Bias, and The Stereotype Content Model. Journal of Business Venturing, 33(6), 813-831. https://doi.org/10.1016/j. jbusvent.2018.04.003

Kim, T., Por, M. H., \& Yang, S. B. (2017). Winning The Crowd in Online Fundraising Platforms: The Roles of Founder and Project Features. Electronic Commerce Research and Applications, 25, 86-94. https://doi.org/10.1016/j.elerap.2017.09.002

Kshetri, N. (2015). Success of Crowd-based Online Technology in Fundraising: An Institutional Perspective. Journal of International Management, 21(2), 100-116. https://doi.org/10.1016/j.intman.2015.03.004

Lee, S., Ahn, C., Song, K. M., \& Ahn, H. (2018). Trust and Distrust in E-Commerce. Sustainability, 10(4), 1015. https://doi.org/10.3390/su10041015

Li, Y., Du, J., \& Fu, W. (2020). Thirty Days Are Enough: What Determines The Crowd's Cash Time in Agri-food Crowdfunding ?, 12(3), 553-575. https://doi.org/10.1108/ CAER-10-2019-0176.

Maehle, N. (2020). Sustainable Crowdfunding: Insights From The Project Perspective, 15(268223), 281-302. https://doi.org/10.1108/BJM-02-2019-0079.

Mariyono, J. (2019). Microcredit and Technology Adoption: Sustained Pathways to Improve Farmers' Prosperity in Indonesia. Agricultural Finance Review, 79(1), 85106. https://doi.org/10.1108/AFR-05-2017-0033.

Mason-D’Croz, D., Sulser, T. B., Wiebe, K., Rosegrant, M. W., Lowder, S. K., NinPratt, A., Willenbockel, D., Robinson, S., Zhu, T., Cenacchi, N., Dunston, S., \& Robertson, R. D. (2019). Agricultural Investments and Hunger in Africa Modeling Potential Contributions to SDG2 -Zero Hunger. World Development, 116, 38-53. https://doi.org/10.1016/j.worlddev.2018.12.006

McIntosh, C., \& Mansini, C. S. (2018). The Use of Financial Technology in the Agriculture Sector. ADBI Working Paper Series No. 872.

Meutia, I., Adam, M., \& Vegirawati, T. (2017). Comparative Analysis of Agricultural Financing in Some Countries. Tazkia Islamic Finance and Business Review, 11(1), 15-38.

Misso, R., \& Cesaretti, G. P. (2017). (2019). Food System and Sustainability: The Role of Crowd-Funding. Innovative Approaches and Applications for Sustainable Rural Development, Springer Earth System Sciences, 01(1), 221-233. https://doi.org/https:// doi.org/10.1007/978-3-030-02312-6_13

Mittelman, R., \& Rojas-Méndez, J. I. (2013). Exploring Consumer's Needs and Motivations in Online Social Lending for Development. Journal of Nonprofit and Public Sector Marketing, 25(4), 309-333. https://doi.org/10.1080/10495142.2013.830544

Moher, D., Shamseer, L., Clarke, M., Ghersi, D., Liberati, A., Petticrew, M., Shekelle, P., Stewart, L. A., \& PRISMA-P Group. (2015). Preferred Reporting Items for Systematic Review and Meta-Analysis Protocols (PRISMA-P) 2015 Statement. Systematic Reviews, 4(1), https://doi.org/10.1186/2046-4053-4-1. 
Morton, S. C., Murad, M. H., O’Connor, E., Lee, C. S., Booth, M., Vandermeer, B. W., Snowden, J. M., D’Anci, K. E., Fu, R., Gartlehner, G., \& Wang Z, S. D. (2016). Methods Guide for Comparative Effectiveness Reviews Quantitative Synthesis An Update. Scientific Resource Center.

Motylska-kuzma, A. (2018). Crowdfunding and Sustainable Development. https://doi. org/10.3390/su10124650

Muhyiddin, M. (2018). Structural Transformation from Agricultural to Manufacturing Sector in Indonesia. (Unpublished Thesis). Universitas Muhammadiyah Malang.

Mujahidin, M. (2019). Opportunities and Challenges of Sharia Technology Financials in Indonesia. MPRA Munich Personal, 94844.

N G Filimonova, M G Ozerova, I. N. E. and N. B. M. (2019). Crowdfunding as the way of projects financing in agribusiness. IOP Conf. Series: Earth and Environmental Science. https://doi.org/10.1088/1755-1315/315/2/022098

Nassiry, D. (2018). The Role of Fintech in Unlocking Green Finance: Policy Insights for Developing Countries.

Nielsen, K. R. (2017). Crowdfunding for Sustainability: A Study on the Potential of Reward-based Crowdfunding in Supporting Sustainable Entrepreneurship. (Unpublished Dissertation). Copenhagen Business School.

Ningrat, R. G., \& Nurzaman, M. S. (2019). Developing Fintech and Islamic Finance Products in Agricultural Value Chain. Journal of Islamic Monetary Economics and Finance, 5(3), 491-516. https://doi.org/10.21098/jimf.v5i3.1077.

Ordanini, A., Miceli, L., Pizzetti, M., \& Parasuraman, A. (2011). Crowd-funding: Transforming Customers Into Investors Through Innovative Service Platforms. Journal of Service Management, 22(4), 443-470. https://doi.org/10.1108/09564231111155079.

Pronti, A., \& Elena, P. (2019). Not Just for Money. Crowdfunding a New Tool of Open Innovation to Support the Agro-Food Sector. Evidences on the Italian Market. Journal of Agricultural \& Food Industrial Organization, 17(1), 1-16.

Rossi, M. (2014). The New Ways to Raise Capital: An Exploratory Study of Crowdfunding. International Journal of Financial Research, 5(2), 8-18. https://doi.org/10.5430/ijfr. v5n2p8.

Sa'ad, A. A., Ahmad, K., \& Saleh, A. O. H. (2019). P2p Islamic Fintech Investment Innovation. A Proposal of Musharakah Smart Contract Model for SMEs Financing and Social Development. Al-Shajarah: Journal of the International Institute of Islamic Thought and Civilization (ISTAC), Special Issue, 169-184.

Saiti, B, Afghan, M., Noordin, N. H. (2018). Financing Agricultural Activities in Afghanistan: A Proposed Salam -Based Crowdfunding Structure. ISRA International Journal of Islamic Finance, 10(1), 52-61. https://doi.org/10.1108/IJIF-09-2017-0029.

Sakinah, N., Purwanti, E., \& Jamilah, S. (2018). Optimalisasi Pembangunan Sektor Pertanian Indonesia dengan Menggunakan Sharia Agraria Manajement Organization (SAMO). Perisai: Islamic Banking and Finance Journal, 2(1), 16-33. https://doi. org/10.21070/perisai.v2i1.1468.

Shaffril, H. A. M., Samah, A. A., Samsuddin, S. F., \& Ali, Z. (2019). Mirror-Mirror 
on The wall, what climate change adaptation strategies are practiced by the Asian's fishermen of all? Journal of Cleaner Production, 232, 104-117. https://doi. org/10.1016/j.jclepro.2019.05.262.

Sierra-Correa, P. C., \& Cantera Kintz, J. R. (2015). Ecosystem-Based Adaptation for Improving Coastal Planning for Sea-Level Rise: A Systematic Review for Mangrove Coasts. Marine Policy, 51, 385-393. https://doi.org/10.1016/j.marpol.2014.09.013.

Smith, J., Feller, J., Gleasure, R., Oreilly, P., Cristoforo, J., \& Shanping, L. (2017). Wise Crowds, Safe Crowds: Balancing Diversity \& Protection in Crowd Investing. Cutter Business Technology Journal, 30(5).

Strzębicki, D. (2015). The Development of Electronic Commerce in Agribusiness The Polish Example. Procedia Economics and Finance, 23, 1314-1320. https://doi. org/10.1016/S2212-5671(15)00573-0.

Suasih, N. N. R., \& Yasa, I. N. M. (2017). Indonesian Eat Rice, But Why Farmers Are Poor? Scientific Papers: Management, Economic Engineering in Agriculture \& Rural Development, 17(3), 403-410.

Syuaib, M. F. (2016). Sustainable Agriculture in Indonesia: Facts and Challenges to Keep Growing in Harmony with Environment. V-Management, Ergonomics and Systems Engineering, 18(2), 170-185.

Teja, A. (2017). Indonesian Fintech Business: New Innovations or Foster and Collaborate in Business Ecosystems? The Asian Journal of Technology Management, 10(1), 10-18.

Tomczak, A., \& Brem, A. (2013). A Conceptualized Investment Model of Crowdfunding. Venture Capital, 15(4), 335-359. https://doi.org/10.1080/13691066.2013.847614.

Utama, M. S. (2013). Potensi dan Peningkatan Investasi di Sektor Pertanian Dalam Rangka Peningkatan Kontribusi Terhadap Perekonomian di Provinsi Bali. Buletin Studi Ekonomi, 18(1), 51-57.

World Bank. (2013). Investing in Agribusiness: A Retrospective View of a Development Bank's Investments in Agribusiness in Africa and Southeast Asia and the Pacific A Retrospective View of a Development Bank's Investments in Agribusiness in Africa and Southeast Asia and the Pacific. World Bank Discussion Paper No. 1.

World Bank Group. (2016). Will Digital Technologies Transform Agriculture in Developing Countries? Policy Research Working Paper No. 7669.

Wright, T., Sugiarti, \& Meylinah. (2016). Indonesia Grain and Feed Update July 2016. Global Agricultural Information Network Number ID1622.

Yoo, Y. G., \& Choe, Y. C. (2014). Current Status of Korean Crowdfunding Industry and its Applicability to Agrifood Sector. Advanced Science Letters, 49(SoftTech), 213-221.

Yuan, H., Lau, R. Y. K., \& Xu, W. (2016). The Determinants of Crowdfunding Success: A Semantic Text Analytics Approach. Decision Support Systems, 91, 67-76. https:// doi.org/10.1016/j.dss.2016.08.001

Zhao, Q., Chen, C. Der, Wang, J. L., \& Chen, P. C. (2017). Determinants of Backers' Funding Intention in Crowdfunding: Social Exchange Theory and Regulatory Focus. Telematics and Informatics, 34(1), 370-384. https://doi.org/10.1016/j.tele.2016.06.006 